\title{
Immune Modulation of Metalloproteinase Production in Human Macrophages \\ Selective Pretranslational Suppression of Interstitial Collagenase and Stromelysin Biosynthesis by Interferon- $\gamma$
}

\author{
Steven D. Shapiro, ${ }^{*}$ Edward J. Campbell," Dale K. Kobayashi, ${ }^{5}$ and Howard G. Welgus \\ Divisions of Dermatology and Respiratory and Critical Care, ${ }^{*}$ Department of Medicine, Jewish Hospital at Washington University \\ Medical Center, St. Louis, Missouri 63110; and Division of Respiratory, Critical Care and Occupational Pulmonary Medicine, ${ }^{*}$ \\ Department of Medicine, University of Utah Health Science Center, Salt Lake City, Utah 84132
}

\begin{abstract}
Interferon- $\gamma($ IFN- $\gamma)$ is a lymphokine that activates mononuclear phagocytes. To test the hypothesis that IFN- $\gamma$ might have important effects upon the ability of human mononuclear phagocytes to degrade extracellular matrix, we have studied the action of this cytokine on the production of metalloproteinases and the counterregulatory tissue inhibitor of metalloproteinases (TIMP) by the human alveolar macrophage. We have found that IFN- $\gamma$ potently and selectively suppresses the lipopolysaccharide-induced production of two metalloproteinases-interstitial collagenase and stromelysin-by $50-90 \%$ at doses $\geq 10 \mathrm{U} / \mathrm{ml}$. The synthesis of TIMP and 92-kD type IV collagenase was also diminished by IFN- $\gamma$, but these responses required 50- to 100 -fold higher concentrations of the cytokine. All doses of IFN- $\gamma$ increased total and secreted protein synthesis slightly, indicating a highly specific effect on metalloenzyme biosynthesis. Inhibition of metalloproteinase expression occurred at a pretranslational level, as evidenced by parallel reductions in enzyme biosynthesis and collagenase-specific steady-state mRNA levels. Interestingly, the effect of IFN- $\gamma$ on metalloenzyme production was not readily reversible. Therefore, while IFN- $\gamma$ activates the macrophage and renders it tumoricidal, this enhanced function appears to be attained at the expense of the cell's capacity to degrade extracellular matrix. (J. Clin. Invest. 1990. 86:1 204-1210.) Key words: interferon- $\boldsymbol{\gamma} \bullet$ macrophages $\bullet$ metalloproteinases $\bullet$ tissue inhibitor of metalloproteinases
\end{abstract}

\section{Introduction}

Macrophages participate in and regulate a wide variety of complex host functions including immune and inflammatory processes as well as degradation and remodeling of extracellular matrix. These cells modulate matrix turnover both directly by secretion of proteinases and proteinase inhibitors $(1,2)$ and indirectly by the elaboration of cytokines, such as interleukin 1 $(3,4)$ and tumor necrosis factor $(5)$, that induce metalloproteinase gene expression by resident fibroblasts of connective tissues. In turn, mononuclear phagocyte function is responsive to signals in the pericellular environment.

Address reprint requests to Dr. Shapiro, Respiratory and Critical Care Division, Jewish Hospital at Washington University Medical Center, St. Louis, MO 63110.

Received for publication 5 February 1990 and in revised form 18 May 1990

J. Clin. Invest.

(C) The American Society for Clinical Investigation, Inc.

$0021-9738 / 90 / 11 / 1204 / 07 \$ 2.00$

Volume 86, October 1990, 1204-1210
Interferon- $\gamma($ IFN- $\gamma)$ is a physiologic mediator that has profound effects on macrophage function. This cytokine, synthesized and released by $\mathrm{T}$ lymphocytes, binds to distinct receptors on the macrophage cell surface $(6,7)$. Receptor binding is followed by complex changes in protein expression and cellular function. IFN- $\gamma$ enhances macrophage antigen presentation by increasing expression of cell surface molecules, including major histocompatibility complex antigens (classes I and II $[8,9])$ and $F_{c}$ receptors for IgG $(10)$. The addition of secondary signals such as lipopolysaccharide (LPS) "fully activates" the IFN- $\gamma$-primed macrophage to become tumoricidal (11). This is achieved, in part, by enhanced expression of tumor necrosis factor (12) and increased secretion of cytolytic proteinases (11). However, the addition of LPS to IFN- $\gamma-$ treated macrophages inhibits the phagocyte's capacity for antigen presentation by reducing the expression of Ia antigens (13). Thus, the macrophage becomes fully tumoricidal at the expense of certain other biologic capacities.

The human macrophage synthesizes and secretes several metalloproteinases that participate in degradation of the extracellular matrix. These include the following: an interstitial collagenase identical to fibroblast-derived collagenase that degrades native collagen types I-III $(2,14,15)$; a $92-\mathrm{kD}$ type IV collagenase that cleaves basement membrane collagen and also efficiently degrades denatured collagens or gelatins (15, 16); stromelysin, an enzyme with broad substrate specificity that attacks proteoglycans and other matrix components such as laminin and fibronectin $(15,17,18)$; and a $72-\mathrm{kD}$ type IV collagenase that has a similar degradative profile to the $92-\mathrm{kD}$ enzyme, but is produced in comparatively small amounts (15, 19). In addition, rodent macrophages have been shown to secrete a $22-\mathrm{kD}$ metalloenzyme with elastolytic properties (20). Macrophages also release the counterregulatory tissue inhibitor of metalloproteinases (TIMP ${ }^{1} ; 2,21-23$ ). The expression of these metalloproteinases and TIMP is subject to the regulatory influences of a number of physiologic and pharmacologic agents $(19,24,25)$. In particular, exposure of macrophages to LPS markedly induces the biosynthesis and secretion of these metalloenzymes, transforming the cells into a matrix-degradative phenotype $(14,15)$.

The present study was performed to test the hypothesis that $T$ lymphocytes, via release of IFN- $\gamma$, might exert important effects upon the ability of the macrophage to degrade extracellular matrix. Our data indicate IFN- $\gamma$ potently and specifically inhibits LPS-induced production of interstitial collagenase and stromelysin without affecting total protein synthesis of the cells. Interestingly, 92-kD type IV collagenase and TIMP pro-

1. Abbreviation used in this paper: TIMP, tissue inhibitor of metalloproteinases. 
duction are also reduced by the cytokine, but only at 50- to 100-fold higher concentrations. These data identify an immune mediator which promotes the activated, tumoricidal macrophage phenotype, yet diminishes the ability of macrophages to degrade extracellular matrix.

\section{Methods}

Reagents. Recombinant IFN- $\gamma\left(2.5 \times 10^{7} \mathrm{U} / \mathrm{mg}\right)$ was kindly provided by Dr. Neal Farber of BioGen Inc., Boston, MA. LPS, derived from Escherichia coli and purified by trichloroacetic acid extraction, was purchased from Sigma Chemical Co., St. Louis, MO. All other chemicals used were reagent grade.

Cell culture. Human alveolar macrophages were harvested from healthy adult volunteers by saline bronchoalveolar lavage (26). To provide adequate yield, only cigarette smokers (more than one pack per day) were selected. The cells obtained were $>95 \%$ macrophages as determined by differential counting of Wright-stained cytocentrifuge preparations. The remaining cells were primarily lymphocytes. The lavaged cells were washed three times in Hanks' balanced salt solution (HBSS) and plated in Linbro six-well cluster plates (Flow Laboratories, Inc., McLean, VA) at a concentration of $2 \times 10^{6}$ cells per well. The cells were incubated for $1 \mathrm{~h}$ at $37^{\circ} \mathrm{C}$ to allow attachment. The HBSS was then exchanged for culture medium and the cell cultures maintained in humidified $95 \%$ air $/ 5 \% \mathrm{CO}_{2}$.

Culture media were obtained from the Tissue Culture Support Center, Washington University Medical Center. The media used consisted of a 1:1 (vol/vol) mixture of Ham's F-12/Dulbecco's modified Eagle's medium (Ham's/DME) supplemented with $10 \%$ fetal calf serum (low endotoxin; $<0.02 \mathrm{ng} / \mathrm{ml}$; HyClone Laboratories, Logan, UT). Methionine-free culture media were used for metabolic labeling experiments.

Collection of conditioned media. All macrophage cultures were exposed to nutrient media alone or media containing IFN- $\gamma$ for $24 \mathrm{~h}$. For the next $48 \mathrm{~h}$, the cells were treated with identical fresh media in the presence or absence of LPS $(2.5 \mu \mathrm{g} / \mathrm{ml})$. This preincubation procedure was followed for all experiments except those addressing order of addition and reversibility of IFN- $\gamma$ effect (see legends to Figs. 8 and 9, respectively). Samples were analyzed either by enzyme-linked immunosorbent assay (ELISA) (unlabeled conditioned media) or by immunoprecipitation of labeled secreted proteins. In metabolic labeling experiments, cells were treated for $24 \mathrm{~h}$ with LPS, after which the media were aspirated, the cell layers were washed twice with HBSS, and otherwise identical fresh methionine-free media containing 50 $\mu \mathrm{Ci} / \mathrm{ml}$ of $\left[{ }^{35} \mathrm{~S}\right]$ methionine (Amersham Corp., Arlington Heights, IL) were added for the final $24 \mathrm{~h}$ of incubation. Serum used during metabolic labeling was dialyzed against $0.05 \mathrm{M}$ Tris, $0.15 \mathrm{M} \mathrm{NaCl}, \mathrm{pH} 7.5$, to remove free amino acids. Preliminary work (not shown) demonstrated that macrophage collagenase and TIMP secretion in the presence of such dialyzed serum was identical to that observed in whole serum.

Immunologic assays. Competitive-binding ELISAs for human fibroblast collagenase and TIMP were performed on macrophage-conditioned media samples and cell extracts as described previously (27, 28). These assays have nanogram sensitivity, are specific for the respective proteins, and measure total amounts of each protein whether present in a free or bound (i.e., complexes of enzyme-inhibitor, enzyme-substrate) state. Owing to minimal cross-reactivity between human and bovine TIMP, conditioned media samples containing $10 \%$ FBS were corrected for their small contribution of bovine TIMP $(0.01$ $\mu \mathrm{g} / \mathrm{ml}$ of immunoreactive material). This represents $<5 \%$ of the TIMP produced by human macrophages and resulted in a negligible background.

Metabolic labeling and immunoprecipitation studies. Cells were metabolically labeled with $\left[{ }^{35} S\right]$ methionine as described above. Polyclonal antisera to human interstitial collagenase (29), 92-kD type IV collagenase $(15,30)$, stromelysin (17), and TIMP (28) were generated as described previously. The following procedure was employed for immunoprecipitation of labeled secreted proteins. $400 \mu \mathrm{l}$ of mononuclear phagocyte conditioned media was mixed with an equal volume of $0.8 \%$ Triton X-100 in phosphate-buffered saline (PBS) containing $0.1 \%$ bovine serum albumin (for stromelysin only, the samples were first incubated with $0.1 \%$ SDS at $37^{\circ} \mathrm{C}$ for $15 \mathrm{~min}$ before adding the Triton-containing buffer). The mixtures were then incubated on ice for $10 \mathrm{~min}$ with $100 \mu \mathrm{l}$ of a $50 \%$ slurry of protein-A Sepharose. After centrifugation, the appropriate antisera were added to the supernatants and kept at $4^{\circ} \mathrm{C}$ overnight. After this incubation, $100 \mu$ l of SDS sample buffer containing $2 \% \beta$-mercaptoethanol was added to the samples and heated at $60^{\circ} \mathrm{C}$ for $15 \mathrm{~min}$. The samples were then applied to $10 \%$ polyacrylamide slab gels and electrophoresis was performed as described by King and Laemmli (31). The gels were equilibrated with En ${ }^{3}$ Hance (New England Nuclear, Boston, MA) for $1.5 \mathrm{~h}$, rinsed in cold distilled water for $1 \mathrm{~h}$, and then dried under vacuum. The dried gels were exposed to Kodak XAR-5 X-Omat film (Eastman Kodak Co., Rochester, NY) at $-70^{\circ} \mathrm{C}$.

Determination of total protein synthesis. Total protein synthesis was determined by the incorporation of $\left[{ }^{3} \mathrm{H}\right]$ leucine into trichloroacetic acid-precipitable protein. Freshly harvested alveolar macrophages were cultured for $24 \mathrm{~h}$ in serum-containing media with or without added IFN- $\gamma$. The cells were then exposed to identical fresh media in the presence or absence of LPS for an additional $24 \mathrm{~h}$. The media were then aspirated, the cell layers washed twice with HBSS, and otherwise identical but leucine-free media added containing $10 \mu \mathrm{Ci} / \mathrm{ml}$ of $\left[{ }^{3} \mathrm{H}\right]-$ leucine (Amersham Corp.). The fetal calf serum used during metabolic labeling was dialyzed against $0.05 \mathrm{M}$ Tris, $0.15 \mathrm{M} \mathrm{NaCl}, \mathrm{pH} 7.5$, to remove free amino acids. All cultures were pulsed for $18 \mathrm{~h}$, after which the conditioned media were collected and the cell extracts were prepared.

The conditioned media samples and cell extracts were subjected to precipitation in cold $10 \%$ trichloroacetic acid using bovine serum albumin as a carrier protein $(1 \mathrm{mg} / \mathrm{ml})$. The reaction mixtures were vortexed and incubated on ice for $20 \mathrm{~min}$. After centrifugation, the pellets were washed three times in cold $10 \%$ trichloroacetic acid, then resuspended in PBS, and counted in a liquid scintillation spectrometer.

RNA isolation and slot blot analysis. Total cellular RNA was isolated by guanidinium phenol extraction (32). $1 \mu \mathrm{g}$ of RNA was dissolved in $6 \times \mathrm{SSC} / 7.4 \%$ formaldehyde and heated to $60^{\circ} \mathrm{C}$ for $10 \mathrm{~min}$ before slotting on nitrocellulose paper equilibrated in $20 \times \operatorname{SSC}(3 \mathrm{M}$ $\mathrm{NaCl}, 0.3 \mathrm{M} \mathrm{Na}$ citrate). The filters were dried in a vacuum at $80^{\circ} \mathrm{C}$ for $2 \mathrm{~h}$ before prehybridization in $50 \%$ formamide, $5 \times$ SSC, $50 \mathrm{mM}$ $\mathrm{NaHPO}_{4}, \mathrm{pH} 7.5,5 \times$ Denhardt's solution, and $0.1 \%$ SDS containing $100 \mu \mathrm{g} / \mathrm{ml}$ denatured and sonicated salmon sperm DNA. Hybridization was performed at $42^{\circ} \mathrm{C}$ overnight with $\gamma$ collagenase and $\beta$-actin cDNA probes (33) that were random primer labeled to specific activity $2 \times 10^{7} \mathrm{cpm}$. The filters were then washed three times for $5 \mathrm{~min}$ with $0.1 \% \mathrm{SDS} / 2 \times \mathrm{SSC}$ at room temperature, followed by two $15-\mathrm{min}$ washes in $0.1 \mathrm{SSC} / 0.1 \% \mathrm{SDS}$ at $55^{\circ} \mathrm{C}$. The filters were dried and then subjected to autoradiography for $24-48 \mathrm{~h}$ at $-70^{\circ} \mathrm{C}$.

\section{Results}

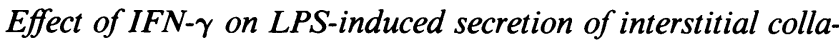
genase. The effect of increasing concentrations of IFN- $\gamma$ on the LPS-stimulated secretion of immunoreactive interstitial collagenase is shown in Fig. 1. Macrophages spontaneously released only small amounts of collagenase, as assessed by ELISA of 48-h-conditioned media samples. However, as reported previously (14), the addition of LPS induced a marked stimulation of collagenase production. Pretreatment of the cells with increasing doses of IFN- $\gamma$ for $24 \mathrm{~h}$ before the addition of LPS resulted in a dose-dependent inhibition of collagenase secretion. Of note, collagenase production was suppressed by a mean of $50 \%$ by $10 \mathrm{U} / \mathrm{ml}$ of IFN- $\gamma$, with even 


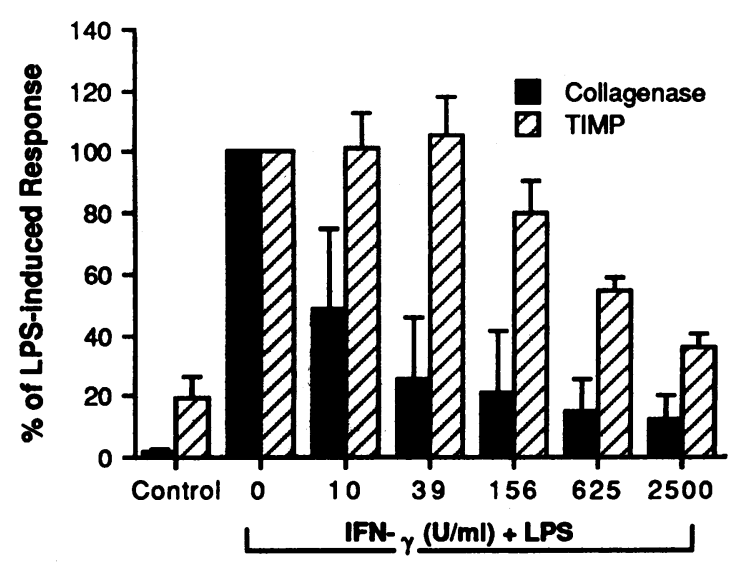

Figure 1. Dose response of human macrophage interstitial collagenase and TIMP production to IFN- $\gamma$. Macrophages were exposed to varying doses of IFN- $\gamma$ for $24 h$, followed by LPS for the next $48 \mathrm{~h}$ as detailed in Methods. Control macrophages were not exposed to either agent. Conditioned media were collected and collagenase and TIMP were quantified by ELISA. The results are expressed as a fraction of the LPS-induced secretory response. Note that collagenase production is suppressed by low doses of IFN- $\gamma$, whereas TIMP production is inhibited only by very high concentrations of the cytokine. Error bars are standard deviations ( $n=4$ subjects).

greater ablation observed at higher cytokine concentrations. In addition to the four subjects' macrophages shown in Fig. 1, cells from three additional individuals displayed similar degrees of inhibition.

Fig. 2 demonstrates the time course of IFN- $\gamma$ suppression of LPS-stimulated interstitial collagenase secretion. Characteristically, and as reported previously $(2,14,15)$, the LPS induction of collagenase was delayed for $\sim 24 \mathrm{~h}$ after exposure to endotoxin, presumably reflecting the time required for signal transduction, biosynthesis, and subsequent release of newly formed procollagenase. As shown in Fig. 2, LPS stimu-

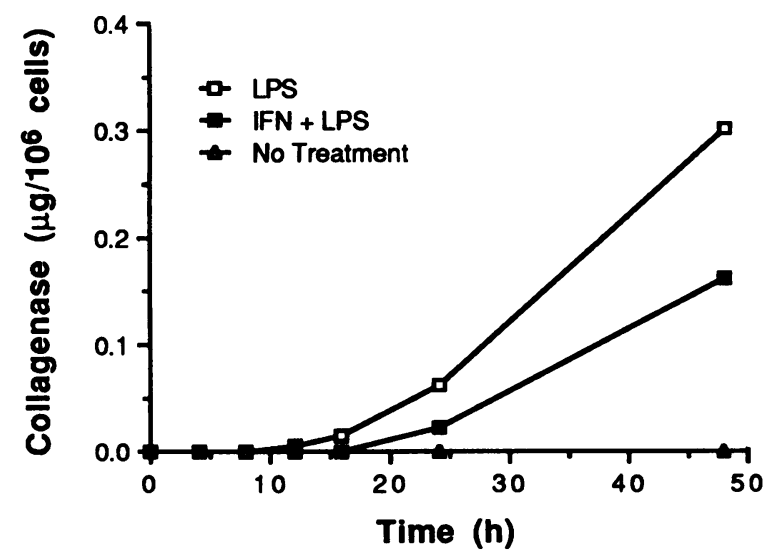

Figure 2. Time course of IFN- $\gamma$ suppression of LPS-induced interstitial collagenase production. Macrophages were exposed to LPS ( 2.5 $\mu \mathrm{g} / \mathrm{ml})$, IFN- $\gamma(10 \mathrm{U} / \mathrm{ml})$ plus LPS, or neither agent as described in Methods. Conditioned media were collected after various times of exposure; collagenase was determined by ELISA. Note that basal levels of collagenase are undetectable, whereas LPS induces collagenase release, observable after $24 \mathrm{~h}$ of exposure. This LPS-induced response is significantly inhibited by $10 \mathrm{U} / \mathrm{ml}$ of IFN- $\gamma$. lation was blunted from its inception in cells pretreated with IFN- $\gamma$.

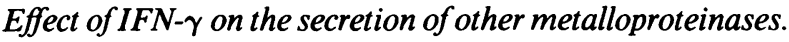
To study enzyme biosynthesis, cells were metabolically labeled with $\left[{ }^{35} \mathrm{~S}\right]$ methionine. Conditioned media were processed by immunoprecipitation using antisera specific for interstitial collagenase, stromelysin, and 92-kD type IV collagenase. Fig. 3 demonstrates that untreated alveolar macrophages spontaneously synthesized only small amounts of collagenase. LPS exposure markedly increased enzyme biosynthesis, whereas pretreatment of the cells with IFN- $\gamma$ profoundly ablated this effect. Note that the dose-response relationship for IFN- $\gamma$ suppression of collagenase biosynthesis is similar to that observed for steady-state production levels shown in Figs. 1 and 2.

In a parallel manner to interstitial collagenase, macrophages failed to spontaneously synthesize measurable levels of stromelysin. As shown in Fig. 4, LPS induced a substantial release of this enzyme. IFN- $\gamma$, at a concentration of only 10 $\mathrm{U} / \mathrm{ml}$, virtually abolished stromelysin production, an effect similar to its action on the synthesis of interstitial collagenase (Fig. 3).

The 92-kD type IV collagenase is a major biosynthetic product of both the basal and LPS-stimulated alveolar macrophage (Fig. 5, $A-C$ ). However, IFN- $\gamma$ caused only minor and inconsistent effects upon this enzyme's production. Using aliquots of labeled, conditioned media from the same cells as shown in Figs. 3 and 4, where only $10 \mathrm{U} / \mathrm{ml}$ of IFN- $\gamma$ virtually abolished the synthesis of interstitial collagenase and stromelysin, we found that both the basal (Fig. $5 C$ ) and LPS-induced (Fig. $5 \mathrm{~A}$ ) production of $92-\mathrm{kD}$ type IV collagenase were completely unaffected. However, in other experiments using macrophages obtained from different individuals (Fig. $5 \mathrm{~B}$ ), some diminution in the synthesis of this enzyme was observed, but only with very high concentrations of the cytokine.

Effect of IFN- $\gamma$ on TIMP production. Fig. 1 shows macrophage production of TIMP as well as collagenase in response to various signals. IFN- $\gamma$ caused a dose-related suppression of LPS-stimulated TIMP secretion. However, concentrations of the cytokine required to decrease TIMP production were very different from those suppressing interstitial collagenase release. Inhibition of TIMP production required 50-fold higher concentrations of IFN- $\gamma(625 \mathrm{U} / \mathrm{ml}$ to achieve a $50 \%$ reduction in synthesis) than those producing equivalent inhibition of collagenase biosynthesis $(10 \mathrm{U} / \mathrm{ml})$.

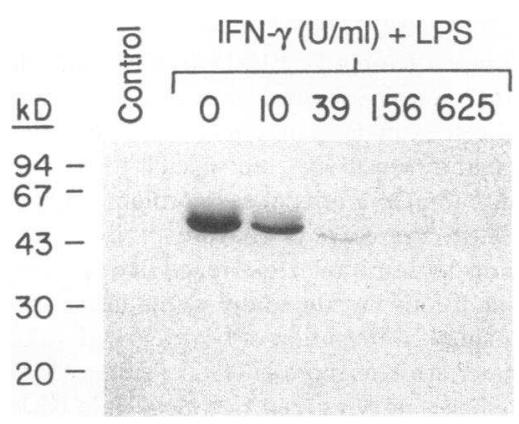

Figure 3. Effect of IFN- $\gamma$ on interstitial collagenase biosynthesis. Macrophages were cultured in the presence of increasing concentrations of IFN- $\gamma$, followed by the addition of LPS $(2.5 \mu \mathrm{g} / \mathrm{ml})$. Control cells were not exposed to either agent. The cells were then incubated in the presence of $\left[{ }^{35} \mathrm{~S}\right] \mathrm{methionine}$ and the labeled secreted proteins were immunoprecipitated with antiserum specific for collagenase. Note the induction of collagenase biosynthesis by LPS and the blockage of this response by very low concentrations of IFN- $\gamma$. 


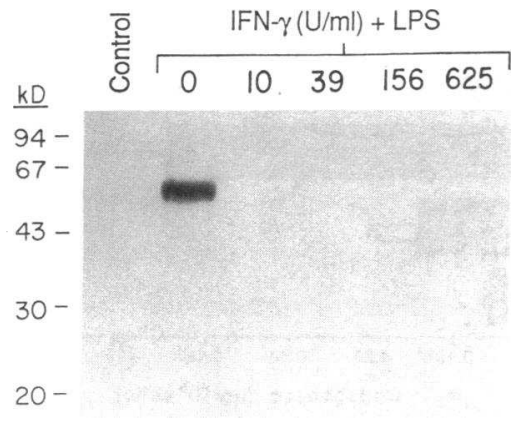
for collagenase in Fig. 3) were immunoprecipitated with antiserum specific for stromelysin. Note the absence of detectable stromelysin production without LPS treatment (control) and the augmented enzyme biosynthesis in response to LPS. This response is ablated by 10 $\mathrm{U} / \mathrm{ml}$ of IFN- $\gamma$.

The time course of immunoreactive TIMP secretion into conditioned media in the presence of IFN- $\gamma$ is shown in Fig. 6. Similar to the results obtained for collagenase (Fig. 2), LPS stimulation of TIMP synthesis was blunted from its inception in cells pretreated with the cytokine.

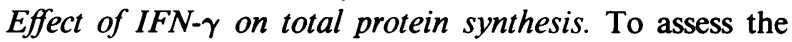
specificity of IFN- $\gamma$ 's capacity to block metalloproteinase production, the synthesis of total intracellular and secreted proteins was examined by trichloroacetic acid precipitation after metabolic labeling of the cells. As shown in Fig. 7, LPS treatment caused a small decrease in intracellular protein synthesis

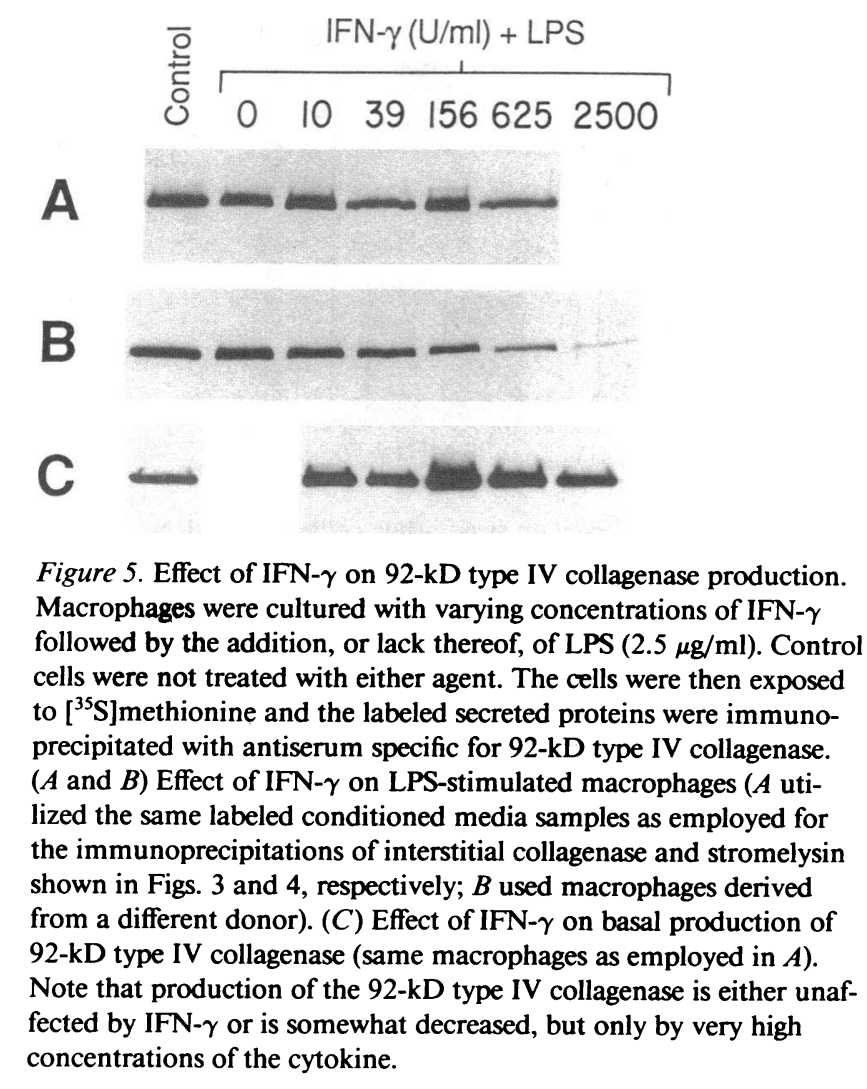

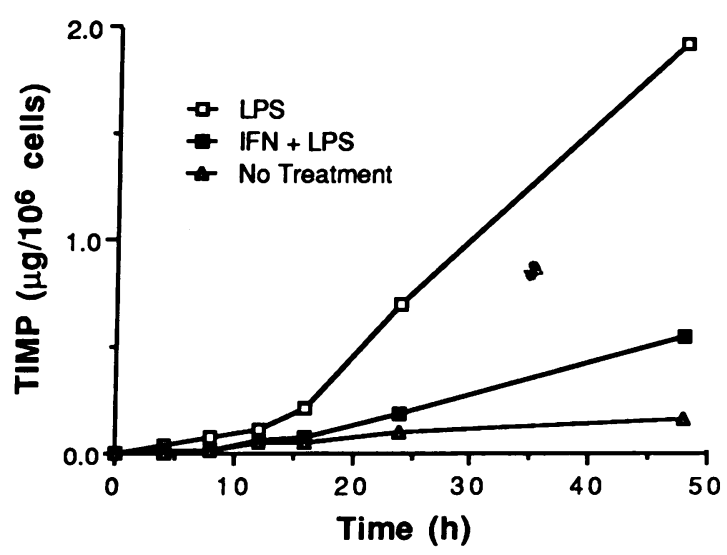

Figure 6. Time course of IFN- $\gamma$ suppression of LPS-induced TIMP production. Macrophages were exposed to LPS ( $2.5 \mu \mathrm{g} / \mathrm{ml})$, IFN- $\gamma$ $(625 \mathrm{U} / \mathrm{ml})$ plus LPS, or neither agent as described in Methods. Conditioned media were collected after various times of incubation and TIMP levels were determined by ELISA. Note that basal amounts of TIMP secreted are very low. LPS induced TIMP release after $24 \mathrm{~h}$ of exposure. This LPS-induced response is significantly blunted, but only by the high concentration of IFN- $\gamma$.

without affecting the synthesis of total secreted proteins. Moderate doses of IFN- $\gamma(\leq 156 \mathrm{U} / \mathrm{ml})$ had little effect on the synthesis of either intracellular or secreted proteins, whereas higher concentrations increased the synthesis of proteins found in the cell layer and secreted into media. These results demonstrate a high degree of specificity of suppression of metalloproteinase and TIMP biosynthesis by IFN- $\gamma$, even in the presence of high concentrations of cytokine.

Mechanism of IFN- $\gamma$ inhibition of collagenase production. To gain information on cellular mechanisms of IFN- $\gamma$ suppression of metalloproteinase synthesis, three types of experiments were performed: order of addition, studies of reversibility, and determinations of steady-state mRNA levels.

Our initial data suggested that IFN- $\gamma$ produced more po-

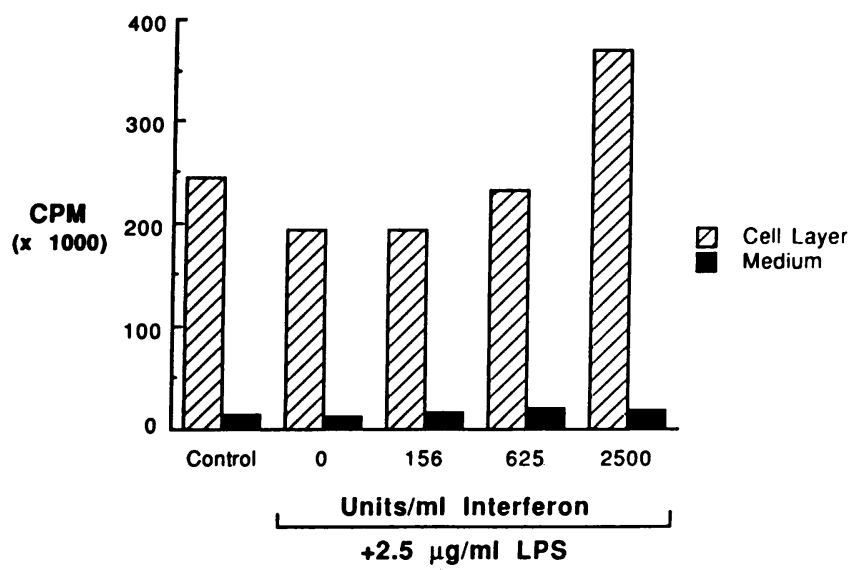

Figure 7. Effect of IFN- $\gamma$ on total protein synthesis by macrophages. Macrophages were exposed to varying doses of IFN- $\gamma$, followed by LPS $(2.5 \mu \mathrm{g} / \mathrm{ml})$, and were then pulsed with $\left[{ }^{3} \mathrm{H}\right]$ leucine for $18 \mathrm{~h}$. Trichloroacetic acid-precipitated lysates or conditioned media from 15,000 cells were counted in a liquid scintillation counter. Note that high concentrations of IFN- $\gamma$ actually augment the biosynthesis of both intracellular and secreted proteins. 
tent inhibition of LPS-induced collagenase biosynthesis when preincubated with alveolar macrophages for $24 \mathrm{~h}$ before the addition of endotoxin. A typical result, shown in Fig. 8, illustrates that such preincubation with $25 \mathrm{U} / \mathrm{ml}$ of IFN- $\gamma$ completely ablated responsiveness of cells subsequently exposed to LPS, whereas co-incubation of the cytokine and endotoxin produced only a $70 \%$ diminution of response.

To study reversibility of the IFN- $\gamma$ effect, cells were first exposed to cytokine $(25$ and $100 \mathrm{U} / \mathrm{ml}$ ) for $24 \mathrm{~h}$, then the cultures were washed and incubated with media for an additional $24 \mathrm{~h}$, after which the macrophages were washed again and media replaced containing LPS alone for the final $48 \mathrm{~h}$ of incubation. As shown in Fig. 9, $>80 \%$ of IFN- $\gamma$ 's inhibitory effect was observed despite the 24-h washout period and without reintroducing the cytokine for the 48-h culture period in the presence of LPS. These results suggest that changes in cellular expression induced by IFN- $\gamma$ are long-lasting and not readily reversible.

Steady-state levels of collagenase mRNA were compared between control and cytokine-treated macrophages that were subsequently subjected to stimulation with LPS. Total cellular RNA was harvested, equal amounts for each condition were applied to slot blots, followed by hybridization with a cDNA specific for collagenase (33). As shown in Fig. 10, IFN- $\gamma$ markedly reduced steady-state collagenase mRNA levels as compared to LPS-treated cells alone. The reduction in collagenase mRNA paralleled the inhibition of secreted collagenase protein. These data indicate that the cytokine exerts its effect at a pretranslational level.

\section{Discussion}

In this report, we have shown that IFN- $\gamma$ is capable of specifically and potently inhibiting the biosynthesis of two metalloproteinases in the human macrophage. The cytokine exerts

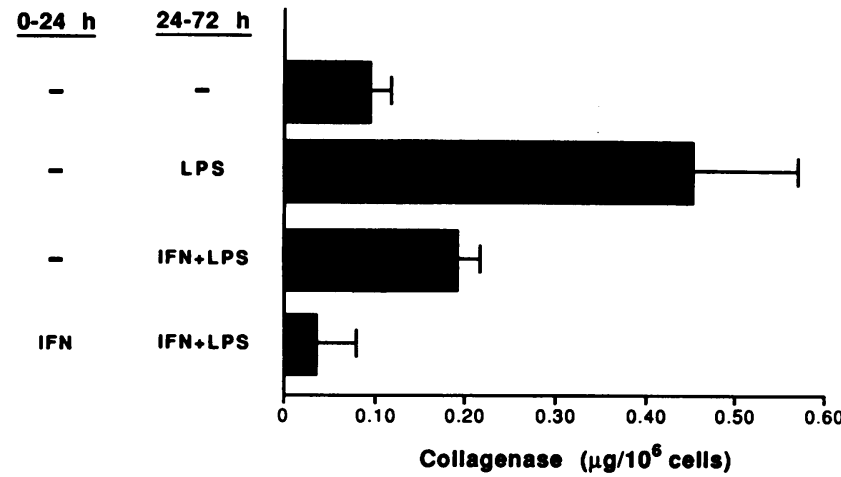

Figure 8. Effect of preincubation vs. co-incubation of IFN- $\gamma$ with LPS on collagenase biosynthesis. Cells were either exposed to IFN- $\gamma$ or media alone (-) for $24 \mathrm{~h}$. From 24 to $72 \mathrm{~h}$ cells were incubated with LPS, IFN- $\gamma$ plus LPS, or media alone as described in the figure. At $72 \mathrm{~h}$ the conditioned media were collected and the amount of interstitial collagenase was quantified by ELISA. Note that simultaneous addition of IFN- $\gamma$ and LPS inhibited induction of collagenase secretion by $70 \%$. However, preincubation of the cells with IFN- $\gamma$ for $24 \mathrm{~h}$ before the addition of LPS totally ablated the endotoxin response. The data are derived from a single patient using duplicate wells and results repeated twice (error bars represent standard deviation).

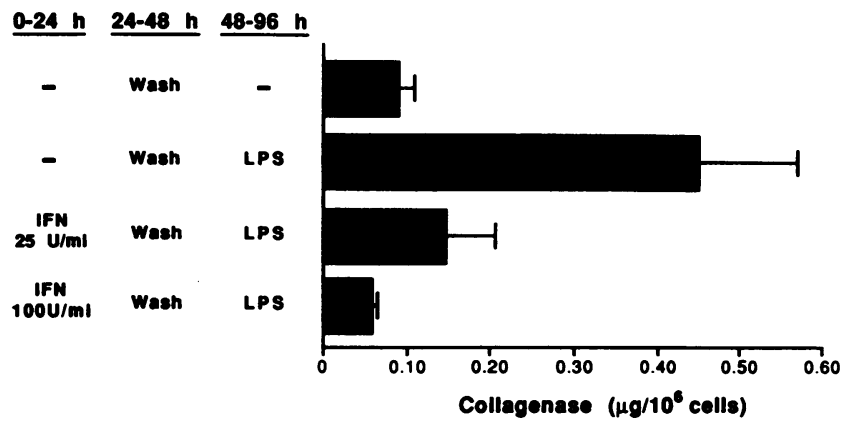

Figure 9. Reversibility of IFN- $\gamma$ inhibition of interstitial collagenase production. Cells were exposed to either IFN- $\gamma(25$ and $100 \mathrm{U} / \mathrm{ml})$ or media alone (-) for $24 \mathrm{~h}$. The cells were then washed, maintained in culture media for hours $24-48$, and then washed again. From 48 to $96 \mathrm{~h}$, the cells were exposed to LPS or media alone as indicated in the figure. At $96 \mathrm{~h}$, the conditioned media were collected and the interstitial collagenase secretion was quantified by ELISA. Note that 25 $\mathrm{U} / \mathrm{ml}$ of IFN- $\gamma$ inhibited LPS-induced collagenase secretion by $85 \%$, whereas $100 \mathrm{U} / \mathrm{ml}$ of IFN- $\gamma$ totally ablated the response. Thus, the effect of IFN- $\gamma$ on macrophages is quite persistent. These experiments were performed on cells from the same subject as in Fig. 8 (error bars represent standard deviation).

this effect upon both interstitial collagenase and stromelysin. While synthesis of 92-kD type IV collagenase and the counterregulatory inhibitor, TIMP, are also suppressed by IFN- $\gamma$, logarithmically higher doses are required to achieve comparably reduced levels of expression. These data strongly suggest that IFN- $\gamma$, a cytokine responsible for activating numerous other

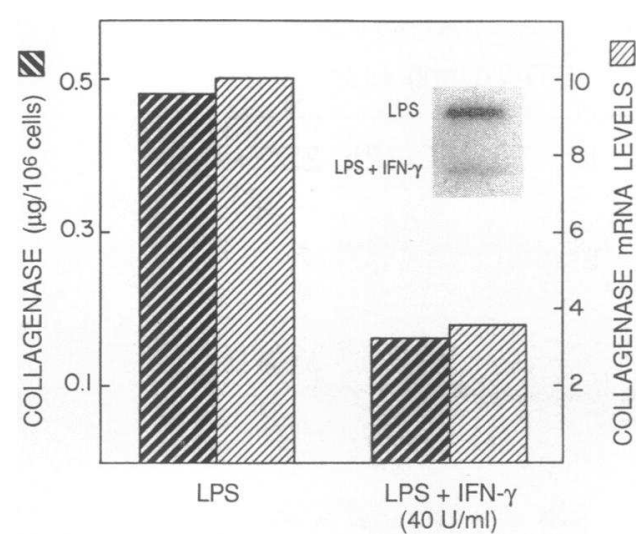

Figure 10. Effect of IFN- $\gamma$ on steady-state collagenase mRNA levels. Macrophages were cultured in the presence of LPS $(2.5 \mu \mathrm{g} / \mathrm{ml})$, or LPS with added IFN- $\gamma(40 \mathrm{U} / \mathrm{ml})$ for $48 \mathrm{~h}$. Total cellular RNA was then harvested by guanidinium phenol extraction and equal amounts of RNA $(1 \mu \mathrm{g})$ were placed on slot blots and hybridized with random-primer-labeled collagenase cDNA, and the blots were subjected to autoradiography. The autoradiographs were scanned densitometrically and the value for LPS-stimulated collagenase mRNA was set arbitrarily to "10." Conditioned media samples were analyzed for collagenase levels by ELISA. Note that IFN- $\gamma$ substantially reduced steady-state collagenase mRNA levels in parallel with secreted collagenase protein. (Inset) slot blots of RNA hybridized to the collagenase cDNA probe. In addition, equal amounts of RNA $(1 \mu \mathrm{g})$ were also hybridized with random-primer-labeled $\beta$-actin cDNA. Neither LPS nor IFN- $\gamma$ plus LPS had any effect on steady-state actin mRNA levels (not shown). 
biologic functions of the macrophage, suppresses the cell's capacity to degrade specific components of extracellular matrix, in particular type I collagen and proteoglycans.

Although the present report does not address specific cellular mechanisms of IFN- $\gamma$ 's suppressive effect on metalloproteinase production, certain insights are provided from the data generated. First, this biologic effect appears to be quite selective, since the cytokine activates many other macrophage functions and since total protein synthesis, both intracellular and secreted, is somewhat enhanced by exposure to this agent. Secondly, the action of IFN- $\gamma$ is quite persistent and is largely unaffected by a $24-72-\mathrm{h}$ washout period (Fig. 9). Thirdly, IFN- $\gamma$ 's action occurs at a pretranslational level. This can be concluded since the diminution in LPS-induced collagenase secretion is paralleled by concomitant decreases in enzyme biosynthesis (Fig. 3) and steady-state levels of collagenase mRNA (Fig. 10). Finally, it seems apparent that biosynthesis of the various mononuclear phagocyte metalloproteinases can be controlled independently, rather than coordinately as a group. Clearly, production of both interstitial collagenase and stromelysin is exquisitely sensitive to IFN- $\gamma$. In contrast, expression of $92-\mathrm{kD}$ type IV collagenase is only minimally affected by the cytokine. Independent regulatory pathways would allow for specific and preferential degradation of certain extracellular matrix components.

Although IFN- $\gamma$ is capable of suppressing both metalloproteinase and TIMP synthesis by macrophages, these effects occur at markedly different IFN- $\gamma$ concentrations. Production of both interstitial collagenase and stromelysin is inhibited $>50 \%$ by doses of $10 \mathrm{U} / \mathrm{ml}$. In contrast, suppression of TIMP production requires concentrations of IFN- $\gamma$ in excess of 500 $\mathrm{U} / \mathrm{ml}$ (Fig. 1). Such higher doses may represent both superphysiologic and superpharmacologic concentrations of the agent. These data suggest that IFN- $\gamma$-mediated suppression of metalloenzyme vs. TIMP biosynthesis must be occurring via different intracellular pathways. In this regard, we have recently shown (34) that despite parallel increases in collagenase/TIMP protein and steady-state mRNA levels with phorbol ester differentiation of U937 cells, the molecular mechanisms of gene induction differ significantly for the two proteins. In any event, it is likely that physiologic concentrations of the cytokine selectively diminish the cell's capacity to express certain metalloproteinases and thereby to degrade specific extracellular matrix components.

The spectrum of proteinases secreted by mononuclear phagocytes varies with the developmental stage of the cell and is also dependent on lymphokines and other biological agents in the extracellular environment. Immature mononuclear phagocytes, such as the human monocyte and the human promonocytic U937 cell line, under basal conditions, contain predominantly neutrophil elastase and cathepsin G, serine proteinases that are characteristically found in azurophilic granules of the neutrophil $(35,36)$. Maturation of the monocyte into a resident tissue macrophage or phorbol-induced differentiation of the U937 cell are associated with a shift in the spectrum of synthesized proteinases away from the serine group to a family of metalloenzymes which include interstitial collagenase, 92-kD type IV collagenase, stromelysin, and $72-\mathrm{kD}$ type IV collagenase $(15,35,36)$. Certain biologic signals, especially LPS, markedly induce the biosynthesis and secretion of these enzymes by fully differentiated macrophages.
The present results underscore the complexity of cell-cell interactions which occur during immune responses. IFN- $\gamma$, a product of $\mathrm{T}$ lymphocytes, has profound effects on macrophage inflammatory and immune capacities (11). The mechanisms of signal transduction after the binding of IFN- $\gamma$ to its macrophage receptor are complex and incompletely understood. Rapid events include ion fluxes with alkalinization of the cytosol followed by efflux of calcium (37). IFN- $\gamma$ markedly alters the expression of individual proteins without significantly changing total protein synthesis (11). Alterations in expression of several proteins have been shown to be under transcriptional control. Some genes, such as the human macrophage $\gamma_{1}$ gene, are strongly activated by IFN- $\gamma$; this upregulation appears to be dependent upon protein kinase C (38).

IFN- $\gamma$ is the principal macrophage-activating factor, and LPS is a prominent second messenger that "fully activates" the cytokine-primed cell $(11,39)$. The inhibition of metalloproteinase production by IFN- $\gamma$ suggests that during the process of becoming an activated macrophage, the cell decreases its ability to degrade, remodel, and traverse the extracellular matrix. Interestingly, both IFN- $\gamma$ and LPS independently increase the expression of tumor necrosis factor. TNF has been shown to have a prolonged stimulatory effect on fibroblast collagenase secretion (40). However, we have been unable to discern any effect of TNF on macrophage secretion of collagenase (Shapiro, S. D., E. J. Campbell, and H. G. Welgus, unpublished observations). The biological significance of the IFN- $\gamma$ inhibition of metalloproteinase secretion is unknown; however, our working hypothesis is that the "activated" macrophage loses some of its capacities, including ability to degrade extracellular matrix, in becoming a specialized tumoricidal and microbicidal cell.

\section{Acknowledgments}

This work was supported by National Heart, Lung and Blood Institute Program Project Grant HL-29594. Support was also derived from Public Health Service grants AR-35805, AR-32087, and AR-07284 from the National Institutes of Health.

\section{References}

1. Senior, R. M., E. J. Campbell, J. A. Landis, F. R. Cox, C. Kuhn, and H. S. Koren. 1982. Elastases derived from human monocyte-like cells: comparisons with elastases derived from human monocytes and neutrophils and murine macrophage-like cells. J. Clin. Invest. 69:384393.

2. Welgus, H. G., E. J. Campbell, Z. Bar-Shavit, R. M. Senior, and S. L. Teitelbaum. 1985. Human alveolar macrophages produce a fibroblast-like collagenase and collagenase inhibitor. J. Clin. Invest. 76:219-224.

3. Dayer, J.-M., J. Breard, L. Chess, and S. M. Krane. 1979. Participation of monocyte-macrophages and lymphocytes in the production of a factor that stimulates collagenase and prostaglandin release by rheumatoid synovium. J. Clin. Invest. 64:1386-1392.

4. Dayer, J.-M., B. deRochemonteix, B. Burrus, S. Demczuk, and C. A. Dinarello. 1986. Human recombinant interleukin-1 stimulates collagenase and prostaglandin E-2 production by human synovial cells. J. Clin. Invest. 77:645-648.

5. Dayer, J.-M., B. Beutler, and A. Cerami. 1985. Cachectin tumor necrosis factor stimulates collagenase and prostaglandin E-2 production by human synovial cells and dermal fibroblasts. J. Exp. Med. 162:2163-2168. 
6. Celada, A., P. W. Gray, E. Rinderknecht, and R. D. Schreiber. 1984. Evidence for a gamma interferon receptor that regulates macrophage tumoricidal activity. J. Exp. Med. 160:55-74.

7. Celada, A., R. Allen, I. Esparza, P. W. Gray, and R. D. Schreiber. 1985. Demonstration and partial characterization of the interferongamma receptor on human mononuclear phagocytes. J. Clin. Invest. 76:2196-2205.

8. Wallach, D., M. Fellous, and M. Revel. 1982. Preferential effect of gamma interferon in the synthesis of HLA antigens and their mRNAs in human cells. Nature (Lond.). 299:833-836.

9. Unanue, E. R. 1984. Antigen-presenting function of the macrophage. Annu. Rev. Immunol. 2:395-428.

10. Fertsch, D., and S. N. Vogel. 1984. Recombinant interferons increase macrophage Fc receptor capacity. J. Immunol. 132:24362439.

11. Adams, D. O., and T. A. Hamilton. 1987. Molecular transductional mechanisms by which IFN-gamma and other signals regulate macrophage development. Immunol. Rev. 97:5-27.

12. Collart, M. A., D. Belin, J. D. Vassalli, S. Kossodo, and P. Vassalli. 1986. Gamma interferon enhances macrophage transcription of the tumor necrosis factor/cachectin, interleukin-1 and urokinase genes, which are controlled by şhort-lived repressors. J. Exp. Med. 164:2113-2118.

13. Steeg, P. S., H. M. Johnson, and J. J. Oppenheim. 1982. Regulation of murine macrophage I-A expression by an immune interferon-like lymphokine: Inhibitory effect of endotoxins. J. Immunol. 129:2402-2406.

14. Cury, J. D., E. J. Campbell, C. J. Lazarus, R. J. Albin, and H. G. Welgus. 1988. Selective upregulation of human alveolar macrophage collagenase production by lipopolysaccharide and comparison to collagenase production by fibroblasts. J. Immunol. 141:4306-4312.

15. Welgus, H. G., E. J. Campbell, J. D. Cury, A. Z. Eisen, R. M. Senior, S. M. Wilhelm, and G. I. Goldberg. Neutral metalloproteinases produced by human mononuclear phagocytes: enzyme profile, regulation, and expression during cellular development. J. Clin. Invest. In press.

16. Hibbs, M. S., J. R. Hoidal, and A. H. Kang. 1987. Expression of a metalloproteinase that degrades native type $\mathrm{V}$ collagen and denatured collagens by cultured human alveolar macrophages. J. Clin. Invest. $80: 1644-1650$

17. Wilhelm, S. M., I. E. Collier, A. Kroneberger, A. Z. Eisen, B. L Marmer, G. A. Grant, E. A. Bauer, and G. I. Goldberg. 1987. Human skin fibroblast stromelysin: structure, glycosylation, substrate specificity, and differential expression in normal and tumorigenic cells. Proc. Natl. Acad. Sci. USA. 84:6725-6729.

18. Chin, J. R., G. Murphy, and Z. Werb. 1985. Stromelysin, a connective tissue-degrading metalloendopeptidase secreted by stimulated rabbit synovial fibroblasts in parallel with collagenase. J. Biol. Chem. 260:12367-12376.

19. Salo, T., T. Turpeenniemi-Hujanen, and K. Tryggvason. 1985. Tumor-promoting phorbol esters and cell proliferation stimulate secretion of basement membrane (type IV) collagen-degrading metalloproteinase by human fibroblasts. J. Biol. Chem. 260:8526-8531.

20. Senior, R. M., N. L. Connolly, J. D. Cury, H. G. Welgus, and E. J. Campbell. 1989. Elastin degradation by human alveolar macrophages: a prominent role of metalloproteinase activity. Am. Rev. Respir. Dis. 139:1251-1256.

21. Stricklin, G. P., and H. G. Welgus. 1983. Human skin fibroblast collagenase inhibitor: purification and biochemical characterization. J. Biol. Chem. 258:12252-12258.

22. Albin, R. J., R. M. Senior, H. G. Welgus, N. L. Connolly, and E. J. Campbell. 1987. Human alveolar macrophages release an inhibitor of metalloproteinase elastase in vitro. Am. Rev. Respir. Dis. 135:1281-1285.
23. Carmichael, D. F., A. Sommer, D. C. Anderson, C. G. Smith, H. G. Welgus, and G. P. Stricklin. 1986. Primary structure and cDNA cloning of human fibroblast collagenase inhibitor. Proc. Natl. Acad. Sci. USA. 83:2407-2411.

24. Harris, E. D., Jr., H. G. Welgus, and S. M. Krane. 1984. Regulation of mammalian collagenases. Collagen Relat. Res. 4:493-512.

25. Bauer, E. A., T. W. Cooper, J. S. Huang, J. Altman, and T. F. Deuel. 1985. Stimulation of in vitro human skin collagenase expression by platelet-derived growth factor. Proc. Natl. Acad. Sci. USA. 82:4132-4136.

26. Senior, R. M., E. J. Campbell, and B. Villager. 1981. Obtaining and culturing alveolar macrophages. Methods for Studying Mononuclear Phagocytes. In D. O. Adams, P. J. Edelson, and H. S. Koren, eds. Academic Press, Inc., New York. 69-83.

27. Cooper, T. W., E. A. Bauer, and A. Z. Eisen. 1982. Enzymelinked immunosorbent assay for human skin collagenase. Collagen Relat. Res. 3:205-216.

28. Welgus, H. G., and G. P. Stricklin. 1983. Human skin fibroblast collagenase inhibitor: comparative studies in human connective tissues, serum, and amniotic fluid. J. Biol. Chem. 258:12259-12264.

29. Stricklin, G. P., E. A. Bauer, J. J. Jeffrey, and A. Z. Eisen. 1977. Human skin collagenase: isolation of precursor and active forms from both fibroblast and organ cultures. Biochemistry. 16:1607-1615.

30. Wilhelm, S. M., I. E. Collier, B. L. Marmer, A. Z. Eisen, G. A. Grant, and G. I. Goldberg. 1989. SV40-transformed human lung fibroblasts secrete a 92-kDA type IV collagenase which is identical to that secreted by normal human macrophages. J. Biol. Chem. 264:1721317221.

31. King, J., and U. K. Laemmli. 1971. Polypeptides of the tail fibers of bacteriophage T4. J. Mol. Biol. 62:465-477.

32. Chomczynski, P., and N. Sacchi. 1987. Single-step method of RNA isolation by acid guanidinium thiocyanate-phenol-chloroform extraction. Anal. Biochem. 162:156-159.

33. Goldberg, G. I., S. M. Wilhelm, A. Kroneberger, E. A. Bauer, G. A. Grant, and A. Z. Eisen. 1986. Human fibroblast collagenase: Complete primary structure and homology to an oncogene transformation-induced rat protein. J. Biol. Chem. 261:6600-6605.

34. Shapiro, S. D., W. C. Parks, E. J. Campbell, A. Kahn, and H. G. Welgus. 1989. Gene regulation of collagenase and TIMP biosynthesis during differentiation of mononuclear phagocytes utilizing the U937 cell line. J. Cell Biol. 109:135a. (Abstr.)

35. Senior, R. M., N. L. Connolly, E. J. Campbell, H. G. Welgus, and D. Burnett. 1987. Human mononuclear phagocytes produce different proteinases at different stages of differentiation: Observations with TPA-differentiated U-937 cells. In Pulmonary Emphysema and Proteolysis. J. C. Taylor and C. Mittman, editors. Academic Press, Inc. Orlando, FL. 219-226.

36. Welgus, H. G., N. L. Connolly, and R. M. Senior. 1986. TPAdifferentiated U937 cells express a macrophage-like profile of neutral proteinases: high levels of secreted collagenase and collagenase inhibitor accompany low levels of intracellular elastase and cathepsin G. $J$. Clin. Invest. 77:1675-1681.

37. Prpic, V., S.-F. Yu, F. Figueiredo, P. W. Hullenbach, G. Gawdi, B. Herman, R. J. Uhing, and D. O. Adams. 1989. Role of $\mathrm{Na}+\mathrm{H}+$ exchange by interferon-gamma in enchanced expression of JE and I-A genes. Science (Wash. DC). 244:469-471.

38. Fan, Z., M. Goldberg, and B. R. Bloom. 1988. Interferongamma-induced transcriptional activation is mediated by protein kinase C. 1988. Proc. Natl. Acad. Sci. USA. 85:5122-5125.

39. Ucla, C., P. Roux-Lombard, S. Fey, J.-M. Dayer, and B. Mach. 1990. Interferon gamma drastically modified the regulation of interleukin-1 genes by endotoxin in U937 cells. J. Clin. Invest. 85:185-191.

40. Brenner, D. A., M. O'Hara, P. Angel, M. Chojkier, and M. Karin. 1989. Prolonged activation of jun and collagenase genes by tumor necrosis factor-alpha. Nature (Lond.). 337:661-663. 